\title{
Systematic study on some Urticaceae Juss. species from Egypt
}

\author{
Mohamed A. Salim \\ Botany Department, Faculty of Science, Ain Shams University, Cairo, Egypt \\ Corresponding author: mohamed.salim@sci.asu.edu.eg
}

\begin{abstract}
Five out of six species belonging to the three genera of Urticaceae were collected from different location in Egypt and subjected in this study. Pollen and seed external morphological characters beside stem and lamina internal characters were examined and photographed using both Light (LM) and Scanning Electron (SEM) Microscopes to assess the use of the studied characters in the separation and identification of species. The most diagnostic characters of both stem and lamina were; dissected or continuous siphonostelic structure of the vascular tissue, dorsiventral lamina, cystolith, stinging hairs, ruminate, rugose or colliculate epidermal cell surface. As well as the shape, size, aperture type and the exine ornamentation of the pollen grains, in addition to seed surface ornamentations. These characters can be of help in the discrimination of the studied species. The most obvious variable characters obtained in constructing an artificial taxonomic key for the studied species. All the 37 characters were subjected to the classical cluster analysis (UPGMA) and the principal component analysis (PCA) using PAST version 3.16 software and clearly revealed the splitting of the studied taxa into two clusters and three groups.
\end{abstract}

Key words: Anatomy, cluster analysis, pollen, seed, Urticaceae

\section{Introduction}

Family Urticaceae Juss. (Nettle family) comprises 53 genera and 2625 species worldwide (Christenhusz \& Byng 2016). Members of the family are herbs, shrubs, lianas or small trees and have a subcosmopolitan distribution with most genera and species found in the moist tropics and temperate regions. The taxonomic position of the family has been faced with many opinions and the history of the taxonomic opinions of the family is summarized in table 1 . The family was described by Antoine-Laurent de Jussieu in 1789 under the name "Urticae" and divided its members under three groups based on inflorescence morphology. Gaudichaud (1830) revised the family as "La famille des urticées" and classified the genera into five tribes. Subsequent studies on the family accepted its division into three subfamilies with five tribes (Berg 1977, 1989, Friis 1989b, 1993). Takhtajan (2009) considered it as one of the Urticales along with Ulmaceae, Moraceae, Cannabaceae, Cecropiaceae, while Stevens (2001 onwards) and the recent taxonomic works beside the APG III system (2009) placed it in order Rosales closer to Rosaceae.

The research studies on the morphology of Urticaceae are few, in spite of that we can refer to Gangadhara \& Inamdar (1977), Lersten \& Curtis (1991), Abid et al. (2015) and Hamdy et al. (2016). Members within the Urticaceae show remarkable morphological diversity; the plants are monoecious, dioecious rarely polygamous. The leaves simple, sessile or petiolate with alternate or opposite arrangement. 
Table 1. Taxonomic opinions of the family Urticaceae.

\begin{tabular}{|c|c|c|c|}
\hline Author & Subfamily & Tribes & Studied genera \\
\hline \multirow{5}{*}{$\begin{array}{c}\text { Gaudichaud } \\
\text { (1830) }\end{array}$} & & Urereae & Urtica \\
\hline & & Elatostemeae & \\
\hline & & Boehmerieae & \\
\hline & & Parietarieae & Parietaria \\
\hline & & Forskalieae & Forsskaolea \\
\hline \multirow{5}{*}{ Weddell (1869) } & & Urereae & Urtica \\
\hline & & Procrideae & \\
\hline & & Boehmerieae & \\
\hline & & Parietarieae & Parietaria \\
\hline & & Forskalieae & Forsskaolea \\
\hline \multirow{5}{*}{ Friis (1993) } & & Urticeae & Urtica \\
\hline & & Lecantheae & \\
\hline & & Boehmerieae & \\
\hline & & Parietarieae & Parietaria \\
\hline & & Forskalieae & Forsskaolea \\
\hline \multirow{5}{*}{ Kravtsova (2009) } & Urticoideae & Urticeae & Urtica \\
\hline & Lecanthoideae & Lecantheae & \\
\hline & Boehmerioideae & Boehmerieae & \\
\hline & & Parietarieae & Parietaria \\
\hline & & Forskalieae & Forsskaolea \\
\hline \multirow{6}{*}{ APG III (2009) } & & Boehmerieae & \\
\hline & & Cecropieae & \\
\hline & & Elaostemateae & \\
\hline & & Forsskaoleae & Forsskaolea \\
\hline & & Parietarieae & Parietaria \\
\hline & & Urticeae & Urtica \\
\hline
\end{tabular}

Ducts and internal characters are more interesting within the family, Guerin (1923) studied the mucilaginous cells and lactiferous ducts in the vegetative parts of some taxa and reported the mucilaginous cells in Urtica, Nanocnide, Laportea, Girardinia, Urera and Gyrotaenia and the lactiferous ducts were observed in Urera. Friis \& Wilmot- Dear (1988) investigated and revised tribe Forsskaoleae in which they maintained the two tribes within the tribe based on the inflorescence and floral structure. Metcalfe \& Chalk (1950) reported that the cortex is well developed in stem section with stone cells in Urera but not in other genera, the pericyclic fibers present in the form of isolated strands and the xylem in the form of continuous cylinder traversed by narrow rays in some species. They also reported dorsiventral lamina; glandular, e-glandular, stinging trichomes and anomocytic stomata. Jafari \& Dehghan (2012) studied the anatomical structure of aerial organs in four populations of Urtica dioica. Hamdy et al. (2016) studied the anatomical features of stem and leaf of Forsskaolea tenacissima growing in Egypt.

Pollen grain morphology done by Sorsa \& Huttunen (1975), they found that the structure, size of the pores and exine sculpture were considered the most diagnostic pollen characteristics. Friis (1989 


\section{Systematic study on some Urticaceae Juss. species from Egypt}

b) reported that the pollen grains of the family are small sized, oblate to suboblatespheroidal, porate (two to six pores) or foraminate (up to 15), with more or less obscure exine sculpture. He observed that in tribe Urticeae the pollen triporate, sometimes polyporate (four to seven pore) with small sized grains varies from 10- $29 \mu \mathrm{m}$ while in Nanocnide, Urera and Hesperocnide the pores are wider, more regularly and densely placed spinules exine sculpture.

The seed morphological characters were significant and useful in revealing the taxonomic relationship between the species of flowering plants (Barthlott 1981; Ather et al. 2010; Kanwal et al. 2012; El-Ghamery et al. 2018). The seed morphology of Urticaceae has been studied by some researchers (Chen et al. 2003; Abid et al. 2015).

In Egypt, this family is represented by seven species belonging to three genera viz. Forsskaolea L., Parietaria L. and Urtica L. (Täckholm 1974), while Boulos (1999) enumerated six species. The specific objective of the present study is the investigation of the morphological characters of stems, lamina, pollen grains and seeds (macro- and micro-characters) to evaluate the weight of these characters in the delimitation and identification between the studied species of Urticaceae growing in Egypt. As well as to realize the nearest similar taxa and their differentiations and recognition by constructing artificial key for the studied species.

\section{Materials:}

In the present study, field trips have been done to collect five out of six species from their natural habitats in Egypt (Table 2, map 1). Ten individuals from each location have subjected for this investigation. Pieces from the fourth stem internodes and leaf lamina were taken and mounted in F.A.A. solution for sectioning. Samples of flowers and seeds have been collected for laboratory investigations. The identification and synonyms of the studied species followed Täckholm (1974), Boulos (1999) and International Plant Names Index (IPNI). Sample individuals were prepared for herbarium preservation in Botany Department, Faculty of Science, Ain Shams University herbarium (CAIA).

Table 2. Data collection

\begin{tabular}{|c|c|c|c|}
\hline No. & Species & Locality & $\begin{array}{l}\text { Life span / date of } \\
\text { collection }\end{array}$ \\
\hline 1 & $\begin{array}{l}\text { Forsskaolea tenacissima L. } \\
=\text { F. cossoniana Webb }\end{array}$ & South Sinai Governorate (Wadi Feiran) & $\begin{array}{l}\text { Perennial herb } \\
5 \text { / } 2019\end{array}$ \\
\hline 2 & $\begin{array}{l}\text { Parietaria alsinifolia Delile } \\
\text { = Freirea alsinaefolia (Delile) Gaudich. }\end{array}$ & $\begin{array}{l}\text { South Sinai Governorate, Saint Katherine } \\
\text { protectorate (Wadi El-Arbaeen) }\end{array}$ & $\begin{array}{l}\text { Perennial herb } \\
5 \text { / } 2019\end{array}$ \\
\hline 3 & $\begin{array}{l}\text { P. judaica L. } \\
=\text { P. diffusa Mert. \& W. D. J. Koch } \\
=\text { P. punctata Willd. }\end{array}$ & $\begin{array}{l}\text { Botanical garden, Faculty of Science, Ain } \\
\text { Shams University }\end{array}$ & $\begin{array}{l}\text { Perennial herb } \\
6 \text { / } 2019\end{array}$ \\
\hline 4 & Urtica pilulifera L. & $\begin{array}{l}\text { Kafr El- Sheikh Governorate, around } \\
\text { cultivated lands }\end{array}$ & $\begin{array}{l}\text { Annual herb } \\
3 / 2019\end{array}$ \\
\hline 5 & U. urens $\mathrm{L}$. & $\begin{array}{l}\text { Mediterranean Coastal Region, Burg El- } \\
\text { Arab (Brimley cave) }\end{array}$ & $\begin{array}{l}\text { Annual herb } \\
\text { 3/ } 2019\end{array}$ \\
\hline
\end{tabular}




\section{Mohamed A. Salim}

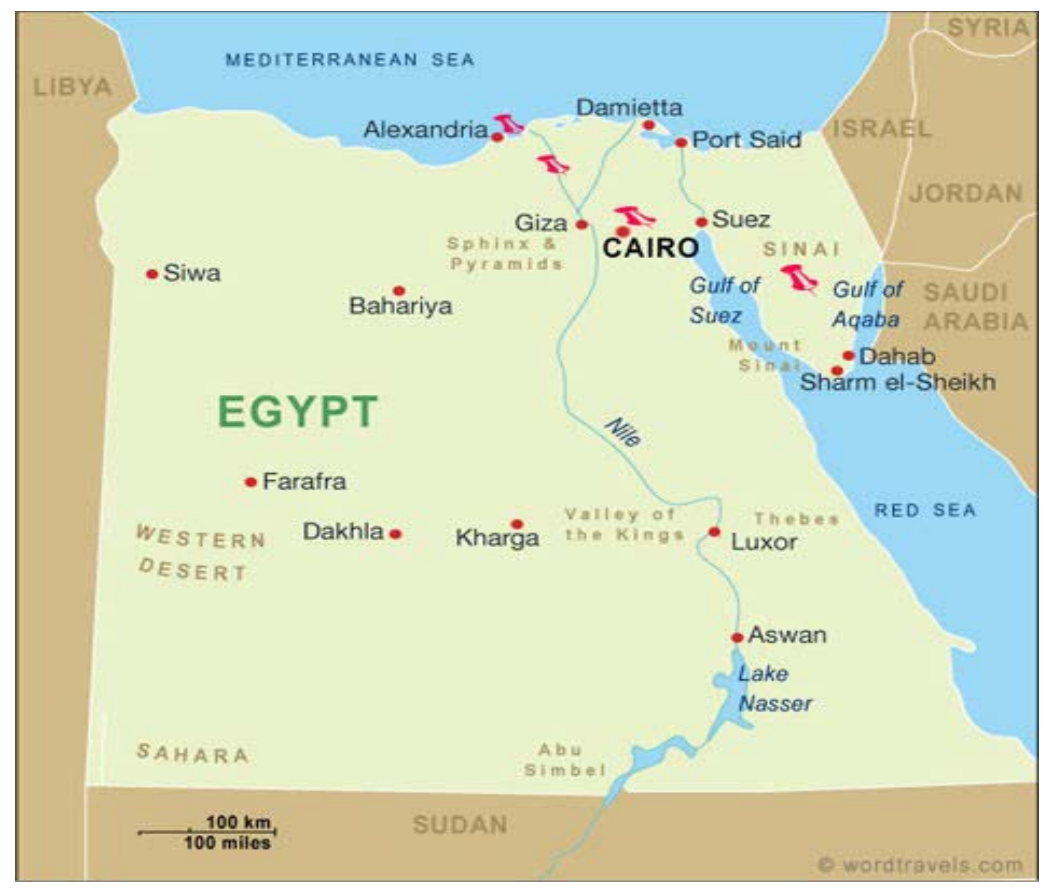

Map 1. Different locations of the studied species

\section{Methods:}

\section{A- Stem and lamina anatomy}

Transverse sections in the fourth internodes of stem and vertical sections in the fourth laminas were done for LM investigation and photography. Sectioning in the studied specimens done by hand microtome at 10-15 $\mu \mathrm{m}$ thick. The sections were double stained using safranine (2\%) and light green (1\%), and finally mounted in Canada Balsam according to the conventional method (Johansen 1940). Sections were examined and photographed using Olympus C.35AD-2. The terminology of the internal structures followed Metcalfe \& Chalk (1950).

\section{B- Lamina epidermal investigation}

Lamina epidermal peels were taken from abaxial surface using forceps and mounted on glass slide directly for light microscope. Examination and photographs were taken using Canon power-shot A470, 7.1 mega pixels. For SEM investigation, small pieces of the cleaned and dried leaves were fixed directly onto EM stubs with double-sided adhesive tape at abaxial surface and coated with 30 nm gold in a DII-29030SCTR Smart Coater, then scanned and photographed using JEOL JSMIT100 SEM at SEM lab, the institute of Nanoscience and Nanotechnology, Kafr El- Sheikh University. Terminology of epidermal cell features followed Stace (1984) and Prabhakar (2004).

\section{C- Pollen grain morphology}

Mature anthers from the collected flowers were carefully opened using sharp needles and sputtered onto glass slides. The pollen grains were examined, measured and photographed using Canon power-shot A470, 7.1 mega pixels. At least ten pollen grains / taxa were measured by LM. Polar axis (P), equatorial diameter (E) and exine thickness were measured. Other pollen characters viz., size, shape and aperture type were recorded. The arithmetic mean value was calculated and the terminology used for describing pollen grains morphology followed Erdtman (1952), Punt et al. (2007) and Hesse et al. (2009). For SEM investigation, nonacetolyzed pollen grains sputtered onto EM 


\section{Systematic study on some Urticaceae Juss. species from Egypt}

stubs using double-sided cello tape, coated with $30 \mathrm{~nm}$ gold then scanned and photographed using JEOL JSM-IT100 SEM for exine and aperture ornamentations. The terminology used here followed Erdtman (1952).

\section{D- Seed morphology}

Mature seeds (10 - 15 seed from each taxa) were examined using stereo-microscope and photographed by inserting Canon power-shot A470, 7.1 mega pixels camera on the stereomicroscope. Stage micrometer in addition to image $\mathrm{J}$ software was used for seed measurements and calibration. Seed colour, length and width, as well as hilum position were studied by stereomicroscope. For SEM investigation, the mature seeds were mounted onto SM stubs, coated with 30 $\mathrm{nm}$ gold and examined and photographed using JEOL JSM-IT100 SEM. The terminology used followed Barthlott (1981) and Stearn (1992).

\section{E- Numerical analysis}

The studied characters were scored, coded and numerically analyzed using PAST program version 3.16. The principal component analysis (PCA) was performed to assess the degree of similarity inside data matrix by un-weighted pair-group method (UPGMA) generating a dendrogram to detect the relationship between the studied species.

\section{Results}

The morphological characters of the studied species including stem and lamina anatomical characters, lamina epidermal characters, pollen characters as well as seed characters (LM \& SEM) were summarized in tables 3 - 6. Some of the specific structures (micro-photographs) were arranged and illustrated in plates I - IV.

A- Stem and lamina anatomy (Table 3 , Plate I)
Stem ridged and furrowed in Urtica pilulifera and $U$. urens or terete in Forsskaolea tenacissima, Parietaria alsinifolia and $P$. judaica. Epidermis radially elongated in Forsskaolea tenacissima and Urtica pilulifera or tangentially elongated Parietaria alsinifolia, $P$. judaica and $U$. urens. Cuticle thin in Parietaria alsinifolia and $P$. judaica or thick in Forsskaolea tenacissima, Urtica pilulifera and U. urens. In all the studied species, trichomes eglandular unicellular. The cortex of polyhedral parenchyma in Parietaria alsinifolia, polyhedral parenchyma and angular collenchyma in Urtica pilulifera, polyhedral parenchyma, angular collenchyma and chlorenchyma in $U$. urens or polyhedral parenchyma, angular collenchyma and extraxylary fibers in Forsskaolea tenacissima and $P$. judaica. The vascular supply is in the form of dissected siphonostelic structure in Urtica pilulifera and $U$. urens or continuous siphonostelic structure Forsskaolea tenacissima, Parietaria alsinifolia and P. judaica. The xylem at the interfascicular regions is of parenchyma in Urtica pilulifera and $U$. urens or fibers in Forsskaolea tenacissima, Parietaria alsinifolia and P. judaica. Stem hollow in Parietaria alsinifolia and Urtica pilulifera or solid Forsskaolea tenacissima, $P$. judaica and $U$. urens.

The outline of the lamina is flattened, dorsiventral and differentiated into midrib and two wings in all studied species. The epidermis is tangentially elongated in Parietaria alsinifolia and Urtica urens or radially elongated in Forsskaolea tenacissima, $P$. judaica and U. pilulifera. The mesophyll is differentiated into compact palisade parenchyma beneath upper epidermis and spongy parenchymatous tissue. Cystolith detected in Forsskaolea tenacissima and Urtica urens or wanting in Parietaria alsinifolia, $P$. judaica and $U$. pilulifera. In midrib region, the mechanical 


\section{Mohamed A. Salim}

tissue (angular collenchyma) detected adaxially in Parietaria judaica and Urtica pilulifera or wanting in Forsskaolea tenacissima, P. alsinifolia and $U$. urens. The vascular bundles three in Urtica pilulifera or represented by one mass in Forsskaolea tenacissima, Parietaria alsinifolia, $P$. judaica and $U$. urens.

\section{B- Lamina epidermal investigation}

(abaxial surface; Table 4, Plate II)

In all the studied species the shapes of the epidermal cell are irregular with anomocytic stomata and covered by e-glandular unicellular hairs, except in Urtica pilulifera and $U$. urens where the glandular stinging hairs recorded in addition to e-glandular ones. The anticlinal walls sinuate in Parietaria alsinifolia and $P$. judaica or undulate in Forsskaolea tenacissima, Urtica pilulifera and $U$. urens. Sand crystals absent in Forsskaolea tenacissima and Parietaria judaica or present in $P$. alsinifolia, Urtica pilulifera and $U$. urens. The lamina abaxial surface sculpture rugose in Parietaria alsinifolia, ruminate in Forsskaolea tenacissima and $P$. judaica or colliculate in Urtica pilulifera and $U$. urens. The anticlinal wall smooth and narrow in all studied species; raised in Forsskaolea tenacissima and Parietaria judaica or sunken in $P$. alsinifolia, Urtica pilulifera and U. urens. The periclinal wall sunken in Forsskaolea tenacissima and Parietaria judaica or raised in P. alsinifolia, Urtica pilulifera and $U$. urens. The periclinal wall surface granulate in Forsskaolea tenacissima, striate in Parietaria alsinifolia or smooth in $P$. judaica, Urtica pilulifera and U. urens.

C- Pollen grain morphology (Table 5, Plate III)

The pollen grains considered small, as the polar axis never exceed $25 \mu \mathrm{m}$, irregular in shape, infolding, asymmetric and apolar. The shapes of the pollens are either subprolate in Forsskaolea tenacissima or prolatespheroidal in Parieteria alsinifolia, $P$. judaica, Urtica pilulifera and $U$. urens where $\mathrm{P} \backslash \mathrm{E}$ ratio was almost homogenous. The apertures are pantoaperturate, pantoporate with very small circular pores except in Parieteria alsinifolia and P. judaica they are panto-colporoidate with small pores. In Urtica pilulifera the pores are surrounded by smooth margo. The number of pores varies from 6-20 ectoexinous in all the studied species. The exine thin, with equal ectexine and endexine, except in Urtica urens the endexine is thicker than the ectexine. The ornamentation of the exine differs between the studied species, as it is tectate punctuate in Urtica pilulifera, tectate granulate in $U$. urens or tectate verrucate in Forsskaolea tenacissima, Parieteria alsinifolia and $P$. judaica.

\section{D- Seed morphology (Table 6, Plate IV)}

The seed color is black and shiny in Parietaria judaica, off-white in Urtica urens and brown in Forsskaolea tenacissima, $P$. alsinifolia and $U$. pilulifera. The seed shape oblong ovate in Forsskaolea tenacissima, obovate in Urtica urens or ovate in Parietaria alsinifolia, $P$. judaica and $U$. pilulifera. The hilum basal in all studied species (depressed in Urtica pilulifera and $U$. urens and semi-depressed in Forsskaolea tenacissima, Parietaria alsinifolia and $P$. judaica). The surface sculpture rugose in Forsskaolea tenacissima, psilate in Parietaria alsinifolia and $P$. judaica or reticulate in Urtica pilulifera and U. urens. The epidermal cell shape polygonal in Forsskaolea tenacissima, irregular in Urtica pilulifera and $U$. urens or obscure in Parietaria alsinifolia and $P$. judaica. The anticlinal wall raised, straight shape and smooth surface in Forsskaolea tenacissima, Urtica pilulifera and $U$. urens or obscure in elevation, shape and surface in Parietaria alsinifolia and $P$. judaica. The periclinal wall surface granulate in Forsskaolea tenacissima, smooth in Urtica pilulifera and $U$. urens or obscure in Parietaria alsinifolia and $P$. judaica. 


\section{Systematic study on some Urticaceae Juss. species from Egypt}

Table 3. Stem and lamina anatomical characters of the studied species of Urticaceae.

\begin{tabular}{|c|c|c|c|c|c|c|c|c|c|c|c|c|c|c|}
\hline \multirow{4}{*}{ 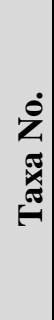 } & \multicolumn{10}{|c|}{ Stem anatomical characters } & \multirow{2}{*}{\multicolumn{4}{|c|}{ Lamina anatomical characters }} \\
\hline & \multirow{3}{*}{ 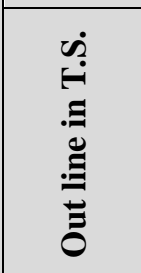 } & \multicolumn{2}{|c|}{ Dermal System } & \multicolumn{5}{|c|}{ Ground System } & \multirow{2}{*}{\multicolumn{2}{|c|}{ Vascular tissue }} & & & & \\
\hline & & \multirow{2}{*}{ 弮 } & \multirow{2}{*}{ 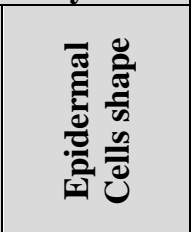 } & \multicolumn{4}{|c|}{$\begin{array}{l}\text { Cortex } \\
\text { Type of Tissues }\end{array}$} & \multirow{2}{*}{ ڤ } & & & \multirow{2}{*}{ 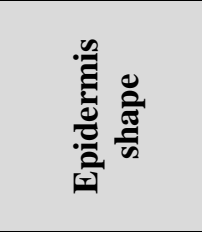 } & \multirow{2}{*}{ 를 } & \multirow{2}{*}{ 竞 } & \multirow{2}{*}{ 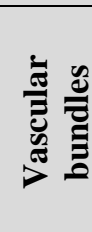 } \\
\hline & & & & 츨 월 & 를 & 壱 & 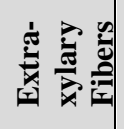 & & $\frac{\ddot{U}}{\ddot{z}}$ & 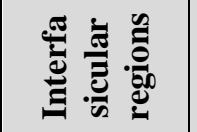 & & & & \\
\hline 1 & Terete & Thick & Radially & $\begin{array}{c}+ \\
2-3 \text { rows }\end{array}$ & - & $\begin{array}{c}+ \\
3-5 \text { rows }\end{array}$ & + & Soild & $\begin{array}{c}\text { Continuous } \\
\text { siphonostele } \\
19-20 \text { bundles }\end{array}$ & $\begin{array}{l}\text { Xylary } \\
\text { fibers }\end{array}$ & Radially & - & + & One \\
\hline 2 & Terete & Thin & Tangentially & - & - & $\begin{array}{c}+ \\
3-5 \text { rows }\end{array}$ & - & Hollow & $\begin{array}{l}\text { Continuous } \\
\text { siphonostele } \\
\text { 10-12 bundles }\end{array}$ & $\begin{array}{l}\text { Xylary } \\
\text { fibers }\end{array}$ & Tangentially & - & - & One \\
\hline 3 & Terete & Thin & Tangentially & $\begin{array}{c}+ \\
2-3 \text { rows }\end{array}$ & - & $\begin{array}{c}+ \\
2-3 \text { rows }\end{array}$ & + & Solid & $\begin{array}{l}\text { Continuous } \\
\text { siphonostele } \\
10-12 \text { bundles }\end{array}$ & $\begin{array}{c}\text { Xylary } \\
\text { fibers }\end{array}$ & Radially & + & - & One \\
\hline 4 & $\begin{array}{l}\text { Ridged\& } \\
\text { furrowed }\end{array}$ & Thick & Tangentially & $\begin{array}{c}+ \\
\text { 3-6 rows }\end{array}$ & - & $\stackrel{+}{5-8 \text { rows }}$ & - & Hollow & $\begin{array}{c}\text { Dissected } \\
\text { siphonostele } \\
\text { 10-12 bundles }\end{array}$ & Parenchyma & Radially & + & - & Three \\
\hline 5 & $\begin{array}{l}\text { Ridged\& } \\
\text { furrowed }\end{array}$ & Thick & Radially & $\begin{array}{c}+ \\
\text { 3-6 rows }\end{array}$ & + & $\stackrel{+}{5-8 \text { rows }}$ & - & Solid & $\begin{array}{c}\text { Dissected } \\
\text { siphonostele } \\
\text { 10-12 bundles }\end{array}$ & Parenchyma & Tangentially & + & + & One \\
\hline
\end{tabular}

$(+)=$ present, (-)= absent, 1: Forsskaolea tenacissima, 2: Parieteria alsinifolia, 3: P. judaica, 4: Urtica pilulifera, 5: U. urens

Table 4. Lamina abaxial epidermal characters of the studied species of Urticaceae.

\begin{tabular}{|c|c|c|c|c|c|c|c|}
\hline \multirow{3}{*}{$\begin{array}{l}\text { Character } \\
\text { Taxa }\end{array}$} & \multirow{2}{*}{\multicolumn{3}{|c|}{$\mathbf{L M}$}} & \multicolumn{4}{|c|}{ SEM } \\
\hline & & & & \multirow[b]{2}{*}{$\begin{array}{c}\text { Surface } \\
\text { sculpture }\end{array}$} & \multirow[b]{2}{*}{$\begin{array}{l}\text { Anticlinal wall } \\
\text { Elevation }\end{array}$} & \multicolumn{2}{|c|}{ Periclinal wall } \\
\hline & $\begin{array}{l}\text { Anticlinal } \\
\text { wall shape }\end{array}$ & $\begin{array}{c}\text { Sand } \\
\text { Crystals }\end{array}$ & Trichomes & & & Elevation & Surface \\
\hline 1 & Undulate & Absent & E-glandular unicellular & Ruminate & Raised & Sunken & Granulate \\
\hline 2 & Sinuate & Present & E-glandular unicellular & Rugose & Sunken & Raised & Striate \\
\hline 3 & Sinuate & Absent & E-glandular unicellular & Ruminate & Raised & Sunken & Smooth \\
\hline 4 & Undulate & Present & E-glandular unicellular\& stinging hairs & Colliculate & Sunken & Raised & Smooth \\
\hline 5 & Undulate & Present & E-glandular unicellular\& stinging hairs & Colliculate & Sunken & Raised & Striate \\
\hline
\end{tabular}

1: Forsskaolea tenacissima, 2: Parieteria alsinifolia, 3: P. judaica, 4: Urtica pilulifera, 5: U. urens 


\section{Mohamed A. Salim}

Table 5. Quantitative and qualitative pollen morphological characters of the studied species of Urticaceae.

\begin{tabular}{|c|c|c|c|c|c|c|c|c|}
\hline \multirow{2}{*}{$\begin{array}{l}\text { Character } \\
\text { Taxa }\end{array}$} & \multirow[b]{2}{*}{ Dimension } & \multirow[b]{2}{*}{ Pollen size } & \multirow{2}{*}{$\begin{array}{l}\text { Shape class as } \\
\text { shown by SEM }\end{array}$} & \multicolumn{3}{|c|}{ Apertures } & \multicolumn{2}{|c|}{ Exine } \\
\hline & & & & Type & Number & Margo & $\begin{array}{l}\text { Ectexine / } \\
\text { Endexine }\end{array}$ & Sculpture \\
\hline 1 & $\begin{array}{c}\mathrm{L}=12.97 \mu \mathrm{m} \\
\mathrm{W}=10.35 \mu \mathrm{m}\end{array}$ & Small & Subprolate & Pantoporate & $10-20$ & Absent & Equal & Verrucate \\
\hline 2 & $\begin{array}{l}\mathrm{L}=15.14 \mu \mathrm{m} \\
\mathrm{W}=13.66 \mu \mathrm{m}\end{array}$ & Small & Prolate - spheroidal & Panto-colporoidate & 6- 10 & Absent & Equal & Verrucate \\
\hline 3 & $\begin{array}{c}\mathrm{L}=10.66 \mu \mathrm{m} \\
\mathrm{W}=10.13 \mu \mathrm{m}\end{array}$ & Small & Prolate - spheroidal & Panto-colporoidate & $6-10$ & Absent & Equal & Verrucate \\
\hline 4 & $\begin{array}{c}\mathrm{L}=22.86 \mu \mathrm{m} \\
\mathrm{W}=21.49 \mu \mathrm{m}\end{array}$ & Medium & Prolate - spheroidal & Pantoporate & 8- 16 & Present & Equal & Punctuate \\
\hline 5 & $\begin{array}{r}\mathrm{L}=8.84 \mu \mathrm{m} \\
\mathrm{W}=8.57 \mu \mathrm{m}\end{array}$ & Small & Prolate - spheroidal & pantoporate & $10-20$ & Absent & $\begin{array}{l}\text { Thicker } \\
\text { endexine }\end{array}$ & Granulate \\
\hline
\end{tabular}

Table 6. Quantitative and qualitative seed morphological characters of the studied species of Urticaceae.

\begin{tabular}{|c|c|c|c|c|c|c|c|c|c|c|c|}
\hline \multirow{2}{*}{$\begin{array}{l}\text { Character } \\
\text { Taxa }\end{array}$} & \multirow[b]{2}{*}{ Color } & \multirow[b]{2}{*}{ Shape } & \multirow{2}{*}{$\begin{array}{c}\text { Dimension } \\
\text { (L x W) } \\
\text { mm } \\
\end{array}$} & \multirow{2}{*}{$\begin{array}{c}\text { Hilum } \\
\text { level }\end{array}$} & \multirow{2}{*}{$\begin{array}{c}\text { Surface } \\
\text { sculpture }\end{array}$} & \multirow{2}{*}{$\begin{array}{l}\text { Epidermal } \\
\text { cell shape }\end{array}$} & \multicolumn{3}{|c|}{ Anticlinal wall } & \multicolumn{2}{|c|}{ Periclinal wall } \\
\hline & & & & & & & Elevation & Shape & Surface & Elevation & Surface \\
\hline 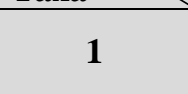 & Brown & $\begin{array}{l}\text { Oblong } \\
\text { ovate }\end{array}$ & $8-10 \times 7-9$ & $\begin{array}{c}\text { Semi- } \\
\text { depressed }\end{array}$ & Rugose & Polygonal & Raised & Straight & Smooth & Depressed & Granulate \\
\hline 2 & Brown & Ovate & $9-11 \times 5-7$ & $\begin{array}{c}\text { Semi- } \\
\text { depressed }\end{array}$ & Psilate & Obscure & Obscure & Obscure & Obscure & Obscure & Obscure \\
\hline 3 & Black & Ovate & $9-11 \times 6-8$ & $\begin{array}{c}\text { Semi- } \\
\text { depressed }\end{array}$ & Psilate & Obscure & Obscure & Obscure & Obscure & Obscure & Obscure \\
\hline 4 & Brown & Obovate & $10-12$ x 8-10 & Depressed & Reticulate & Irregular & Raised & Straight & Smooth & Depressed & Smooth \\
\hline 5 & Off-white & Ovate & $9-11 \times 5-7$ & Depressed & Reticulate & Irregular & Raised & Straight & Smooth & Depressed & Smooth \\
\hline
\end{tabular}

$(\mathrm{L})=$ length, $(\mathrm{W})=$ width. $\quad$ 1: Forsskaolea tenacissima, 2: Parieteria alsinifolia, 3: P. judaica, 4: Urtica pilulifera, 5: U. urens 


\section{Systematic study on some Urticaceae Juss. species from Egypt}
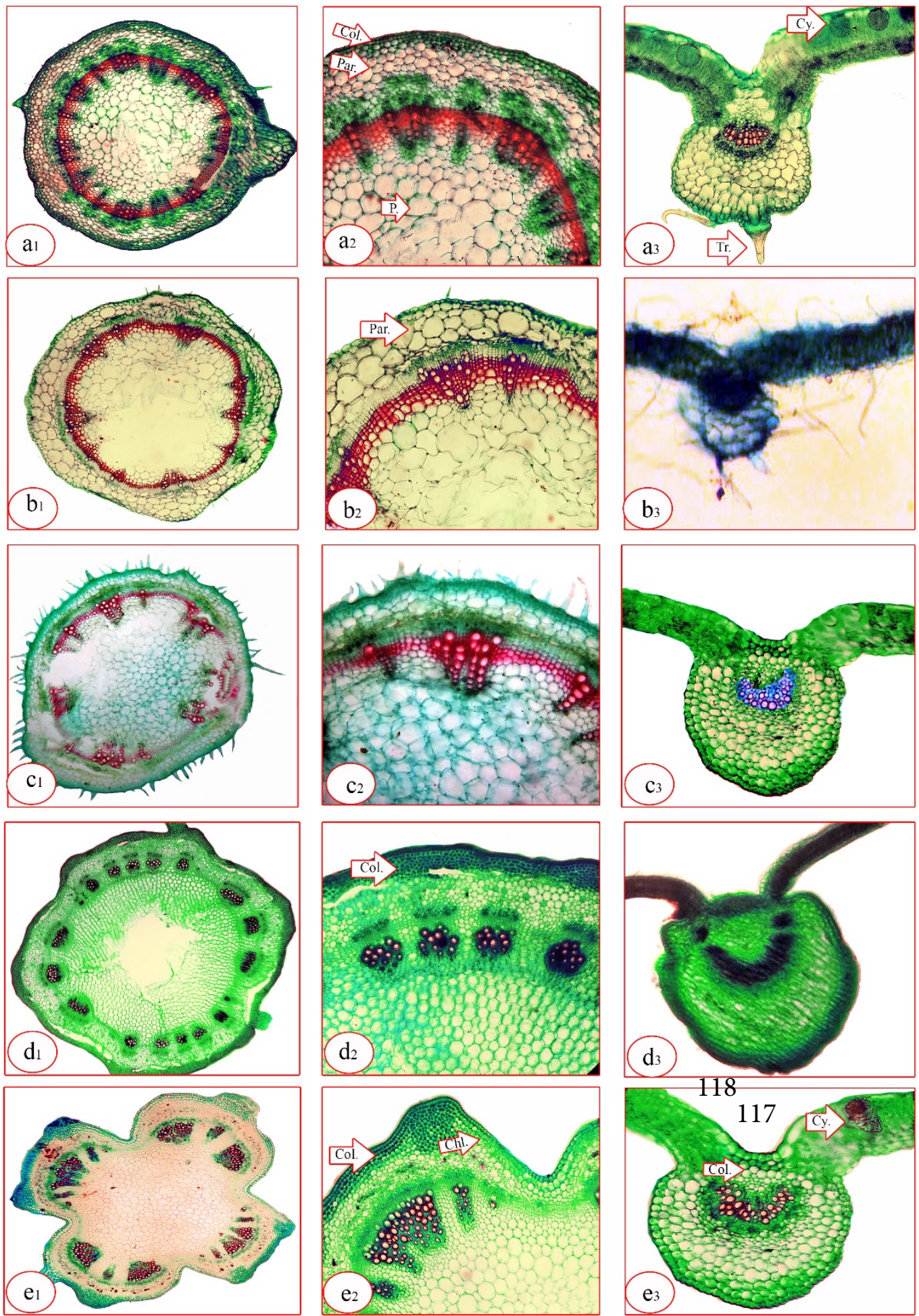

Plate I. Stem and lamina microphotographs showing different growth aspects of the studied species (LM, X= 20). a (1, 2 \& 3): Forsskaolea tenacissima, b (1, 2 \& 3): Parietaria alsinifolia, c (1, 2 \& 3): P. judaica, d (1, 2 \& 3): Urtica pilulifera \& e (1, 2 \& 3): $U$. urens. Chl.; chlorenchyma, Col.; collenchyma, Cy.; cystolith, P.; pith, Par.; parenchyma \& Tr.; trichome. 
Mohamed A. Salim
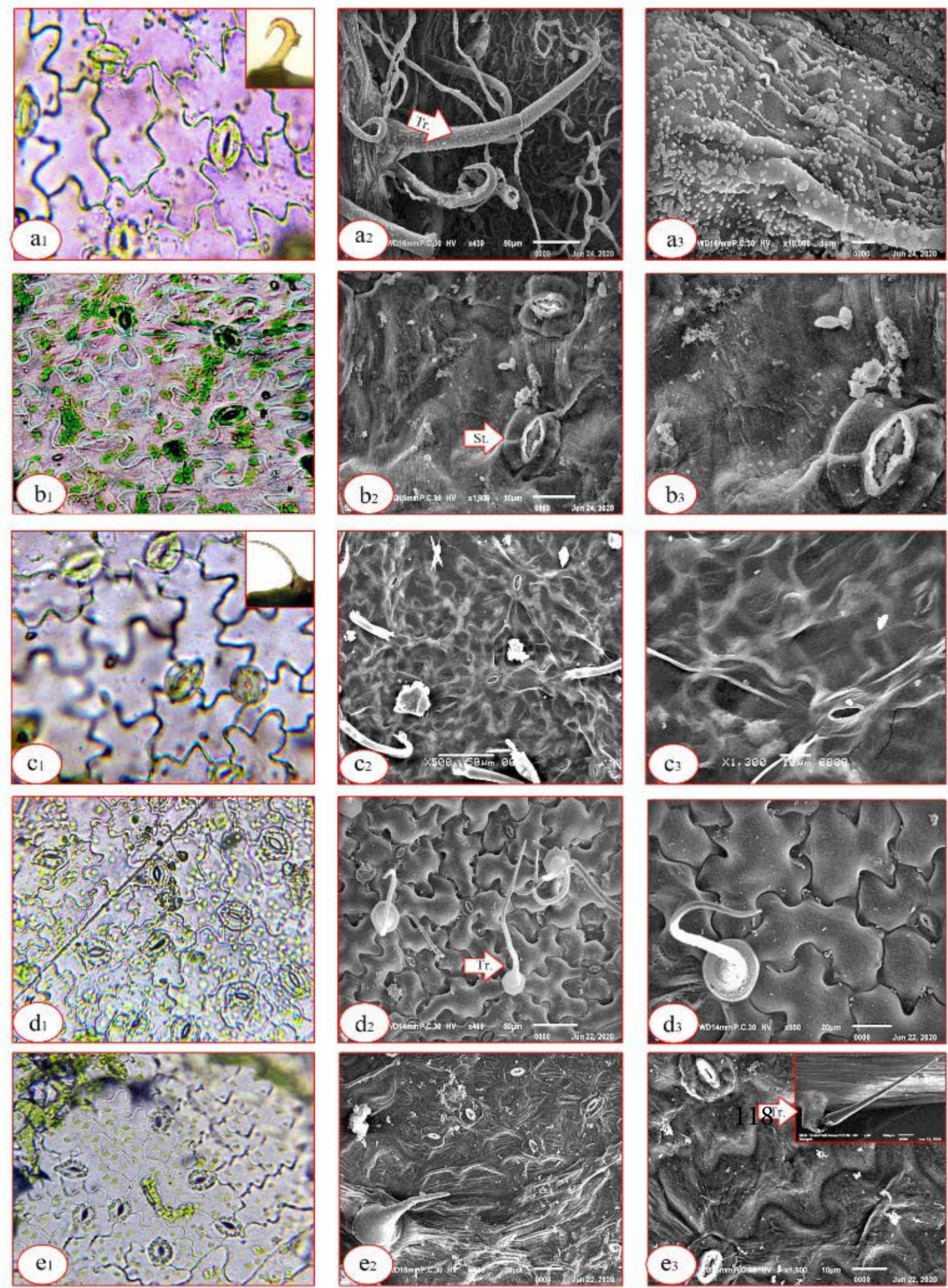

Plate II. Major aspects of lamina epidermal characters of the studied species (LM, X $=20$ \& SEM). a (1, 2 \& 3): Forsskaolea tenacissima, b (1, 2 \& 3): Parietaria alsinifolia, c (1, 2 \& 3): P. judaica, d (1, 2 \& 3): Urtica pilulifera \& e (1, 2 \& 3): U.urens. St.; stomata \& Tr.; trichome. 
Systematic study on some Urticaceae Juss. species from Egypt
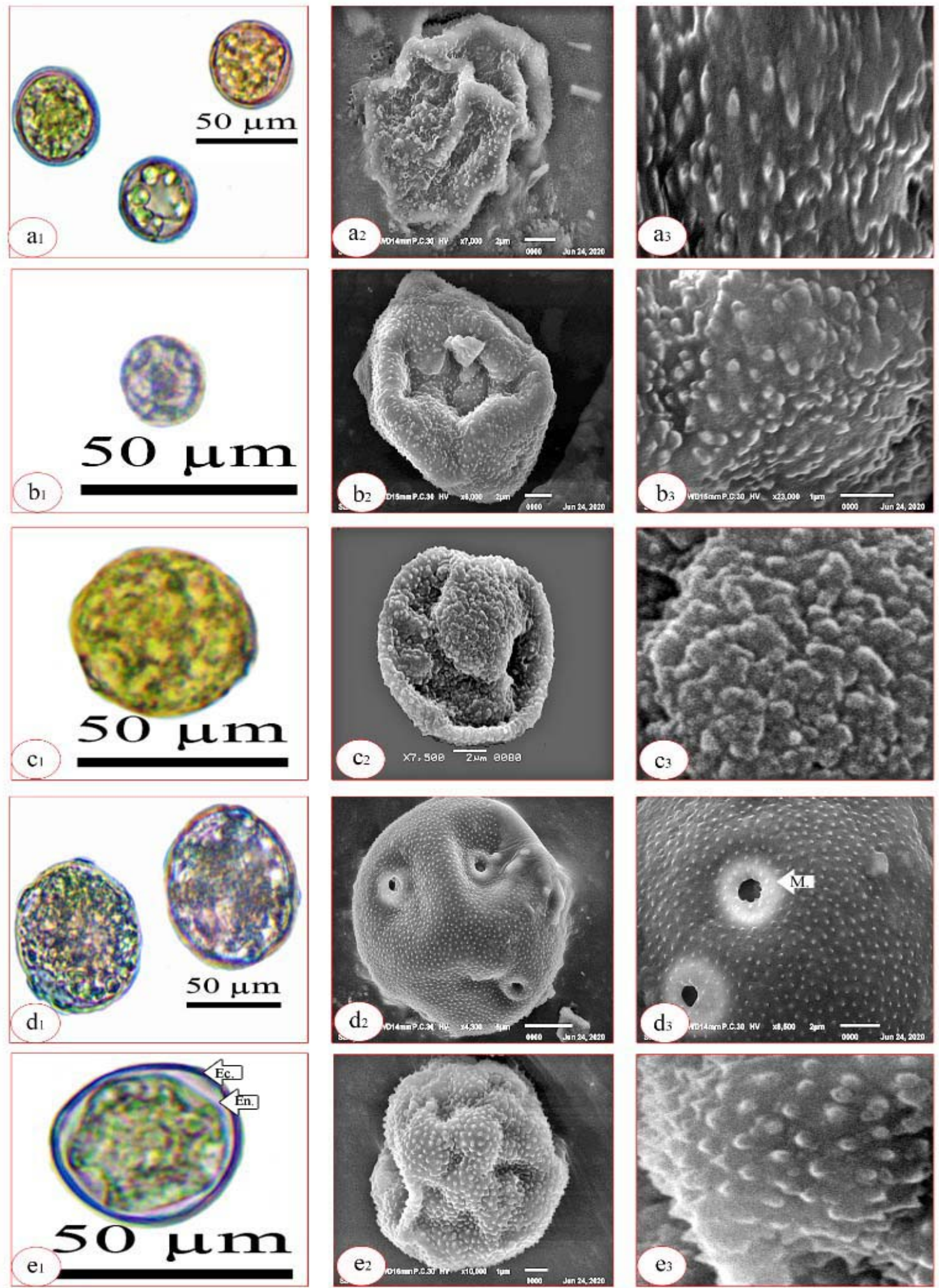

Plate III. Microphotographs of pollen morphology of the studied species (LM \& SEM). a (1, 2 \& 3): Forsskaolea tenacissima, b (1, 2 \& 3): Parietaria alsinifolia, c (1, 2 \& 3): P. judaica, d (1, 2 \& 3): Urtica pilulifera \& e (1, 2 \& 3): U. urens. Ec; ectexine, En; endexine, $\mathrm{M}$; margo 


\section{Mohamed A. Salim}
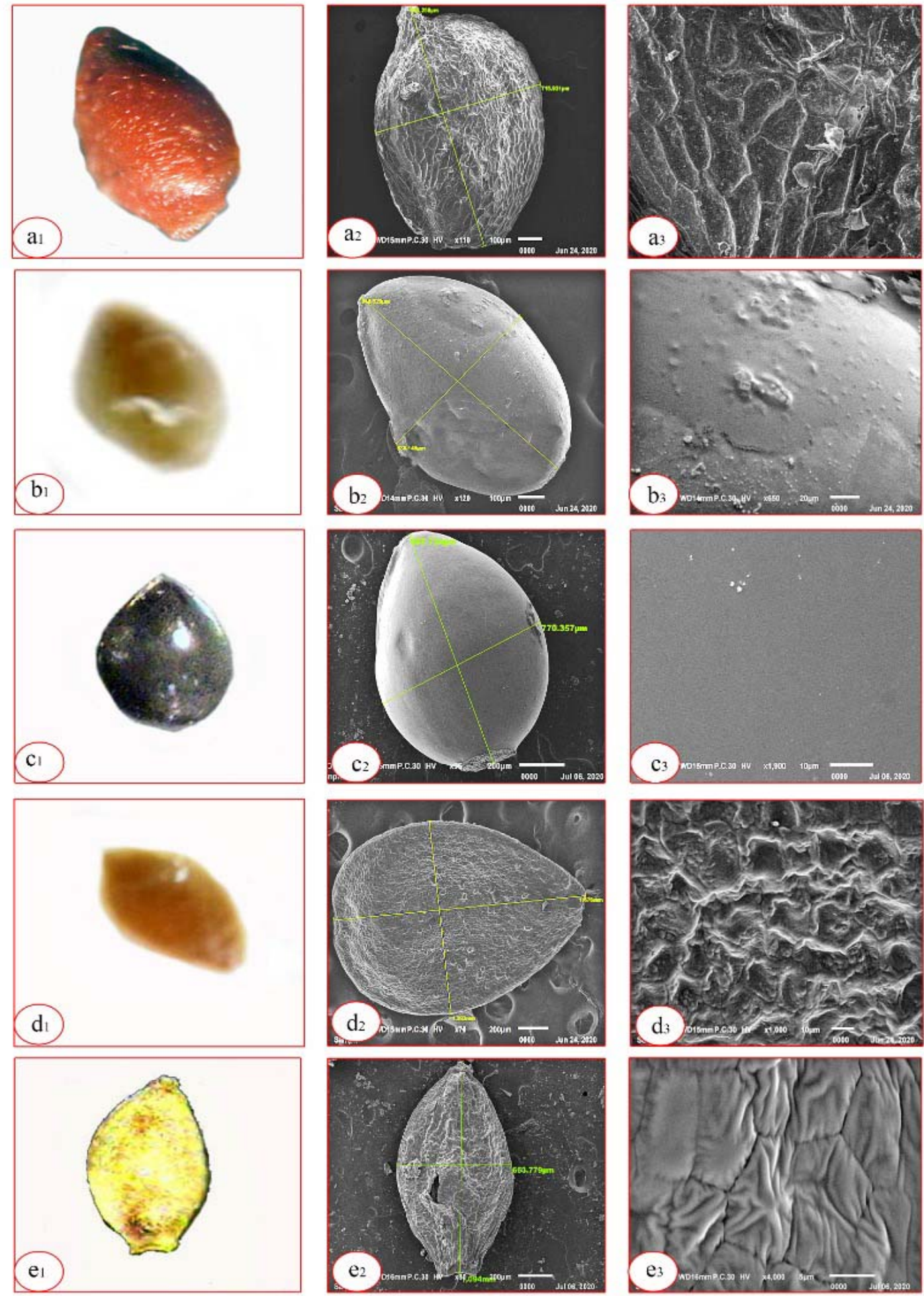

Plate IV. Microphotographs of seed morphology of the studied species (LM \& SEM). a (1, 2 \& 3): Forsskaolea tenacissima, b (1, 2 \& 3): Parietaria alsinifolia, c (1, 2 \& 3): P. judaica, d (1, 2 \& 3): Urtica pilulifera \& e (1, 2 \& 3): U. urens. 


\section{Systematic study on some Urticaceae Juss. species from Egypt}

An artificial key based on the most obvious characters is designed to facilitate the differentiation between the studied species as follow:

1a- Stem vascular tissue in form of dissected siphonostele........................................ 2

1b- Vascular tissue in form of continuous siphonostele..................................

2a- Three vascular bundle present in lamina midrib...................... Urtica pilulifera

2b- One vascular bundle present in lamina midrib........................... Urtica urens

3a- Seed coat ornamentation rugose ........................... Forsskaolea tenacissima

3b- Seed coat psilate.............................................................4

4a- Seed testa black................................................ Parietaria judaica

4b- Seed testa brown.......................................... Parietaria alsinifolia

\section{E- Numerical analysis}

The data were analyzed using the data matrix organized for five OUT's x 37 binary and multistate traits (Table 7). The obtained dendrogram is distinguished into

two clusters and three groups (Fig. 1). The plot of the five OTU's on the first three principal component axes is shown in figures 2 - 4.

Table 7. Characters, character states and their codes used in morphometric analysis of the studied species and the highest factor loading on the first three principal component.

\begin{tabular}{|c|c|c|c|c|c|c|c|c|c|c|c|}
\hline \multirow{2}{*}{ No. } & \multirow{2}{*}{\multicolumn{2}{|c|}{ Character }} & \multirow{2}{*}{ Character state } & \multirow{2}{*}{1} & \multirow{2}{*}{2} & \multirow{2}{*}{3} & \multirow{2}{*}{4} & \multirow{2}{*}{5} & PC 1 & PC 2 & PC 3 \\
\hline & & & & & & & & & \multicolumn{3}{|c|}{ Loading factor } \\
\hline 1 & & Outline & $\begin{array}{l}\text { Ridged \& furrowed (0), } \\
\text { Terete (1) }\end{array}$ & 1 & 1 & 1 & 0 & 0 & -0.161 & -0.030777 & 0.066857 \\
\hline 2 & & Cuticle & Thick (0), Thin (1) & 0 & 1 & 1 & 0 & 0 & -0.089016 & -0.19913 & 0.080171 \\
\hline 3 & & Epidermis & Tangential (0), Radial (1) & 1 & 0 & 0 & 0 & 1 & 0.023482 & 0.21296 & 0.16746 \\
\hline 4 & & Cortex & $\begin{array}{l}\text { Extra xylary fibers (0), } \\
\text { Angular collenchyma (1) }\end{array}$ & 1 & 0 & 1 & 1 & 1 & 0.052267 & 0.093342 & 0.061757 \\
\hline 5 & & Internal appearance & Hollow (0), Solid (1) & 1 & 0 & 1 & 0 & 1 & -0.013267 & 0.10718 & 0.30939 \\
\hline 6 & & Vascular tissue & $\begin{array}{l}\text { Dissected siphonostele (0), } \\
\text { Continuous siphonostele } \\
\text { (1) }\end{array}$ & 1 & 1 & 1 & 0 & 0 & -0.161 & -0.030777 & 0.066857 \\
\hline 7 & $\underset{\Xi}{\stackrel{\Xi}{0}}$ & $\begin{array}{l}\text { Xylem in interfascular } \\
\text { regions }\end{array}$ & Parenchyma (0), Fibers (1) & 1 & 1 & 1 & 0 & 0 & -0.161 & -0.030777 & 0.066857 \\
\hline 8 & $\begin{array}{l}\tilde{\widetilde{\sigma}} \\
\widetilde{\widetilde{\Xi}}\end{array}$ & Lamina epidermis & Tangential (0), Radial (1) & 0 & 1 & 0 & 0 & 1 & 0.043198 & -0.04873 & 0.11902 \\
\hline 9 & 売 & Mechanical tissue & Absent (0), Present (1) & 0 & 0 & 1 & 1 & 1 & 0.12425 & -0.075008 & 0.075071 \\
\hline 10 & 름 & Cystolith & Absent (0), Present (1) & 1 & 0 & 0 & 0 & 1 & 0.023482 & 0.21296 & 0.16746 \\
\hline 11 & $\stackrel{\oplus}{\omega}$ & No. of Vasular bundles & Three (0), One (1) & 1 & 1 & 1 & 0 & 1 & -0.065534 & 0.013835 & 0.24763 \\
\hline 12 & & Anticlinal wall shape & Sinuate (0), Undulate (1) & 1 & 0 & 0 & 1 & 1 & 0.089016 & 0.19913 & -0.080171 \\
\hline 13 & 互 & Sand crystals & Absent (0), Present (1) & 0 & 1 & 0 & 1 & 1 & 0.10873 & -0.062565 & -0.12861 \\
\hline 14 & 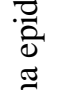 & Trichomes & $\begin{array}{l}\text { E-glandular (0), E- } \\
\text { glandular \& stinging (1) }\end{array}$ & 0 & 0 & 0 & 1 & 1 & 0.161 & 0.030777 & -0.066857 \\
\hline 15 & 罜 & Surface sculpture & $\begin{array}{l}\text { Ruminate (0), Rugose (1), } \\
\text { Colliculate (2) }\end{array}$ & 0 & 1 & 0 & 2 & 2 & 0.26973 & -0.031789 & -0.19547 \\
\hline 16 & & Anticlinal wall elevatio & Sunken (0), Raised (1) & 1 & 0 & 1 & 0 & 0 & -0.10873 & 0.062565 & 0.12861 \\
\hline
\end{tabular}



sculpture

Eigenvalue of principle component

Percentage variance of principle component

Percentage total variation for the first three principal component amounts $12.97 \times 10.35(0), 15.14 \times$ $22.86 \mathrm{x}$
$8.57(4)$ 8-10 x 7-9 (0), 9-11 x 5-7 8-10 (3), 9-11 x 5-7 (4) white (2) (1), Obovate (2) Depressed (1) Reticulate (2) Polygonal (0), Irregular (1), Obscure (2) sculpture

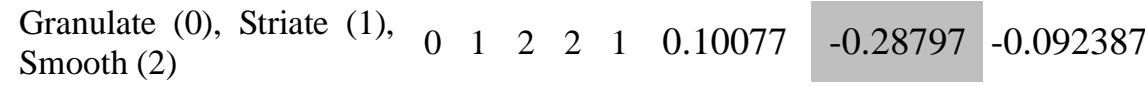
$\begin{array}{llllllll}0 & 1 & 0 & 1 & 1 & 0.10873 & -0.062565 & -0.12861\end{array}$ $13.66(1), 10.66 \times 10.13(2)$,

Medium (0), Small (1) $\quad 1 \quad 1 \quad 1 \quad 1 \quad 0 \quad 1 \quad 1 \quad-0.0655340 .013835 \quad 0.24763$ $\begin{array}{llllllllll}\text { Prolate- spheroidal } & (0), & 1 & 0 & 0 & 0 & 0 & -0.071983 & 0.16835 & -0.013314 \\ \text { Subprolate (1) } & & & & & & \end{array}$

$\begin{array}{llllllllll}\text { Pantoporate (0), } & \text { Panto- } \\ \text { colporoidate (1) } & 0 & 1 & 1 & 0 & 0 & -0.089016 & -0.19913 & 0.080171\end{array}$ 6-10 (0), 8-16 (1), 10-20 (2) $2 \quad 0 \quad 0 \quad 1 \quad 2 \quad 0.1125 \quad 0.41209 \quad 0.087287$ Absent (0), Present (1) $\quad \begin{array}{llllllllll}0 & 0 & 0 & 1 & 0 & 0.065534 & -0.013835 & -0.24763\end{array}$ Equal (0), Thicker (1) $\quad \begin{array}{llllllllll}0 & 0 & 0 & 0 & 1 & 0.095465 & 0.044612 & 0.18077\end{array}$ $\begin{array}{lllllllllll}\text { Verrucate (0), Punctate (1), } & 0 & 0 & 0 & 1 & 2 & 0.25646 & 0.075388 & 0.11391 \\ \text { Granulate (2) }\end{array}$

$\begin{array}{lllllllll}\text { (1), } 9-11 \times 6-8(2), 10-12 \times & 0 & 1 & 2 & 3 & 4 & 0.4527 & -0.16797 & 0.2023\end{array}$

$\begin{array}{llllllllll}\text { Brown (0), Black (1), Off- } & 0 & 0 & 1 & 0 & 2 & 0.15418 & -0.016561 & 0.50347\end{array}$ $\begin{array}{lllllllllll}\text { Oblong ovate (0), Ovate } & 0 & 1 & 1 & 2 & 1 & 0.13752 & -0.18218 & -0.23432\end{array}$

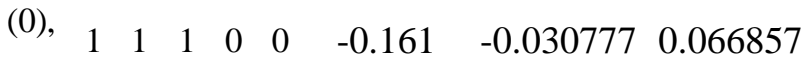
$\begin{array}{lllllllllll}\text { Rugose (0), Psilate (1), } & 0 & 1 & 1 & 2 & 2 & 0.23298 & -0.13757 & -0.053543\end{array}$ $\begin{array}{lllllllll}0 & 2 & 2 & 1 & 1 & -0.017032 & -0.36748 & 0.093485\end{array}$ $\begin{array}{llllllll}1 & 0 & 0 & 1 & 1 & 0.089016 & 0.19913 & -0.080171\end{array}$ $\begin{array}{llllllllll}\text { Obscure (0), Straight (1) } & 1 & 0 & 0 & 1 & 1 & 0.089016 & 0.19913 & -0.080171\end{array}$ $\begin{array}{lllllllllll}\text { Obscure (0), Smooth (1) } & 1 & 0 & 0 & 1 & 1 & 0.089016 & 0.19913 & -0.080171\end{array}$ $\begin{array}{llllllllll}\text { Obscure (0), Depressed } & 1 & 0 & 0 & 1 & 1 & 0.089016 & 0.19913 & -0.080171 \\ (1) & & 1 & \end{array}$ $\begin{array}{llllllllll}\text { Granulate (0), Smooth (1), } & 1 & 2 & 2 & 0 & 0 & -0.25001 & -0.2299 & 0.14703 \\ \text { Obscure (2) }\end{array}$ $11.0268 \quad 4.95773 \quad 2.11626$ $56.839 \quad 25.555 \quad 10.909$ 93.303 


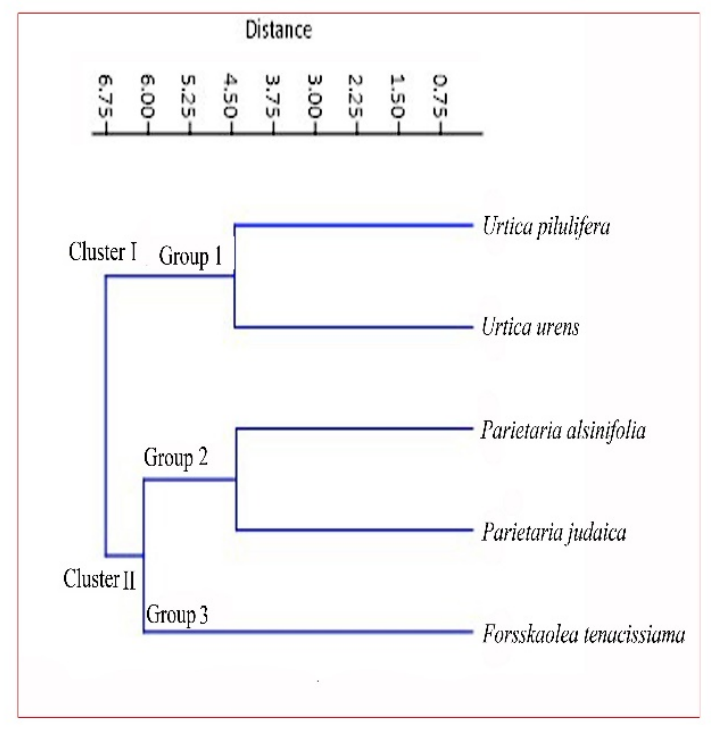

Fig. 1. Dendrogram based on 37 morphological characters of the studied species of Urticaceae.

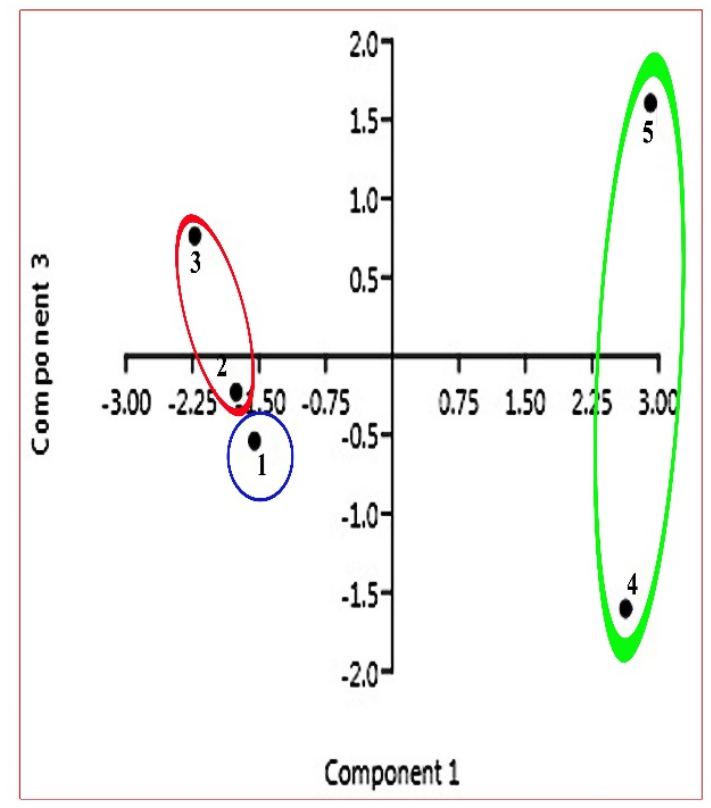

Fig. 3. Scatter plot of the 5 OTU's plotted against the first principal component by the third principal component.

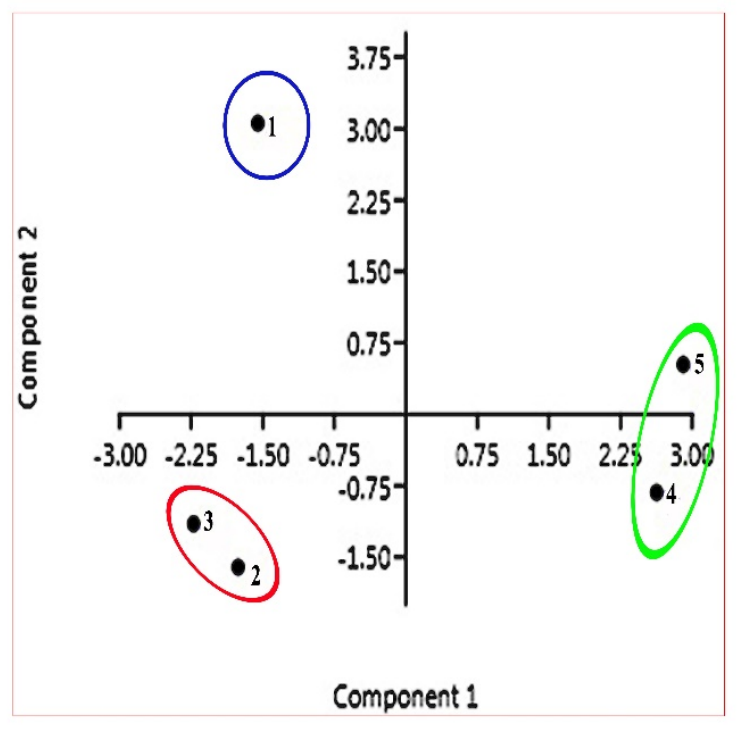

Fig. 2. Scatter plot of the 5 OTU's plotted against the first principal component by the second principal component.

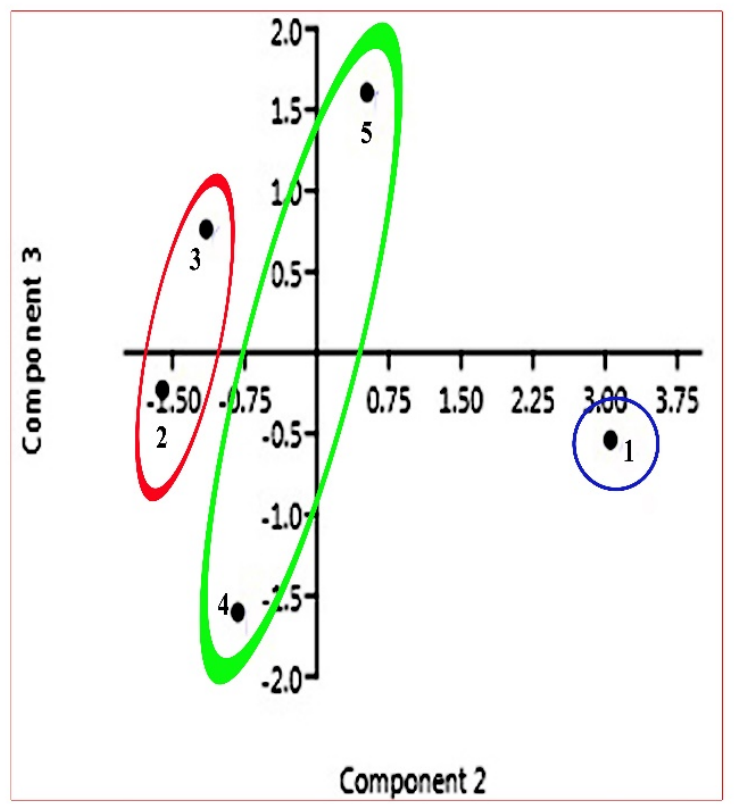

Fig. 4. Scatter plot of the 5 OTU's plotted against the second principal component by the third principal component. 


\section{Mohamed A. Salim}

\section{Discussion}

Family Urticaceae, which have been faced with many taxonomic opinions as shown in table 1 , has been subjected in this study to reveal the dissimilarities between the different taxonomic categories indicated by Gaudichaud (1980), Weddell (1869), Friis (1993), Kravtsova (2009) and APG III (2009). In Egypt the family represented by three genera and six species according to Boulos (1999). These genera have been surveyed and examined externally and internally to clarify their affinities. The variable data obtained (37 character as shown in table 7) have been analyzed using PAST program version 3.16. The studied species has been divided into two clusters with three groups. The first cluster (group 1) gather Urtica pilulifera and U. urens at taxonomic distance 4.50. Cluster II subdivided into two groups (2 and 3 ). The former group includes Parietaria alsinifolia and $P$. judaica at taxonomic distance 4.50 , while the second group has Forsskaolea tenacissima at taxonomic distance 6.00. These divisions separate the genera, each in a separate group with clear separations between the Urtica species than the two other genera. The studied Urtica species have specific characters which distinguished it from the two studied genera as the stem outline and the dissected siphonostelic structure without xylem fibers in between the vascular bundles at xylem region. Urtica species is the only one with stinging glandular trichomes and the seeds have depressed hilum. These notifications have been pointed before by Metcalfe \& Chalk (1950), Jafari \& Dehghan (2012) and Hamdy et al. (2016). The second cluster which separates the other two genera, each in a separate group. The first subgroup (group 2) has the two Parietaria species which distinguished from the Forsskaolea tenacissima (group 3) by having sinuate anticlinal epidermal cell walls, different type of pollen grain aperture, panto-colporoidate apertures and psilate seed coat surface. This separation of the two genera in accordance with seed morphological characters obtained by Abid et al. (2015) who found that Parietaria and Forsskaolea species in the same phenetic clade and far from the Urtica species. As well as, this separation of the studied species coordinates with the obtained artificial key.

The plot of the five OTU's, on the first three principal components axes, shown in figures 2, 3 \& 4 explain 93.303\% of the total observed variation. On the first axis (56.839\% total variance) a segregation is demonstrated between the three groups and the main characters explaining this separation (characters with high factor loading $\geq 0.16$ ) are stem outline, the stem vascular tissue, component of xylem in interfasicular region, trichomes on lamina surface, lamina epidermal surface sculpture, pollen dimension, exine sculpture, seed hilum position, seed surface sculpture and periclinal wall sculpture. The second principal component axis (25.555\% total variance) reveals splitting of the three groups based on stem epidermal cell shape in cross section, cuticle thickness, presence of cystolith in lamina wing, lamina anticlinal walls shape, lamina epidermal periclinal walls sculpture, pollen shape class, aperture type, number of pores per grain, seed shape, seed epidermal cell shape, the anticlinal and the periclinal walls. Along the third axis $(10.909 \%$ total variance) the separation is based on stem epidermal cell shape in cross section, stem internal appearance, presence of cystolith, number of vascular bundles in midrib region in vertical section of lamina, lamina epidermal surface sculpture, pollen size, aperture margo, ectexine/ endexine thickness, seed shape and color. The most specific characters of different organs viz. stem, lamina, pollen and seed characters which facilitate the separation or grouping of the studied species in two clusters and 


\section{Systematic study on some Urticaceae Juss. species from Egypt}

three groups are in accord with Metcalfe \& Chalk (1950), Jafari \& Dehghan (2012), Abid et al. (2015) and Hamdy et al. (2016). The obtained dendrogram (UPGMA) and principal component analysis (PCA) are similar in distinguishing the studied species into three groups, and this is in accord with Ghafoor (1981) and Abid et al. (2015) who splitted the taxa of Utricaceae based on seed morphological characters.

\section{References}

Abid, R.; Afsheen, A. \& Qaiser, M. 2015. The seed atlas of Pakistan- XI. Urticaceae. Pak. J. Bot., 47 (3): 987-994. APG 2009. An update of the Angiosperm Phylogeny Group classification for the orders and families of flowering plants: APG III. Bot. J. Linn. Soc., 161: 105-121.

Ather, A.; Abid, R. \& Qaiser, M. 2010. The Seed Atlas of Pakistan- IV. Oxalidaceae. Pak. J. Bot., 42 (3): 14291433.

Barthlott, W. 1981. Epidermal and seed surface characters of plants: Systematic applicability and some evolutionary aspects. Nord. Journ. Bot., 1: 345-355.

Berg, C. C. 1977. Urticales, their differentiation and systematic position. PI. Syst. Evol., Suppl., 1: 349-374.

Berg, C. C. 1989. Systematics and phylogeny of the Urticales. In: Crane, P. R., Blackmore, S. (Eds.) Evolution, systematics, and fossil history of the Hamamelideae, vol. 2. 'Higher' Hamamelideae. Syst. Ass., Special Volume 40A, Oxford: Clarendon Press: 193-220.

Boulos, L. 1999. Flora of Egypt vol. 1. Al-Hadara publishing, Cairo, Egypt.

Brookes, D. \& Thomas, K. W. 1967. The distribution of pollen grains on microscope slides. I. Part I nonrandomness Distribution. Pollen Spores, 9 (3): 62l - 629. Chen, J.; Qi, L.; Friis, I.; Wilmot-Dear, C. M. \& Monro, A. K. 2003. Urticaceae In: Fl. Chi. Science Press, Beijing. China, 5: 76-189.

Christenhusz, M. J. \& Byng, J. W. 2016. The number of known plants species in the

\section{Conclusion}

The obtained data separates the three genera, each separately, according to their studied characters. This conclusion coordinate with the previous historic works on the family shown in table 1 , as each of the studied genus has been classified in separate tribes. More phylogenetic works must be done for investigation the relationship between the Urticaceae taxa.

world and its annual increase. Phytospecies, 231: 201-2017.

De Jussieu, A. D. (1789). Genera Plantarum, secundum ordines naturales disposita juxta methodum in Horto Regio Parisiensi exaratam. Apud Viduam Herissant, typographum, Paris.

El-Ghamery, A. A.; Hosni, H. A. \& Sadek, A. M. 2018. Pollen and Seed Morphology of Some Endemic Species in Saint Catherine, Sinai, Egypt. Taeckholmia 38: 40-60.

Erdtman, G. 1952. Pollen Morphology and Plant Taxonomy. Angiosperms. Almqvist and Wiksell, Stockholm, 539.

Friis, I. 1989b. The Urticaceae: a systematic review. In: Crane, P. R., Blackmore, S. (Eds.) Evolution, systematics, and fossil history of the Hamamelideae, vol. 2, 'Higher' Hamamelideae. Systematics Ass., Special Volume 40B, Oxford: Clarendon Press: 285-308.

Friis, I. 1993. Urticaceae. Pp. 612-630 in: Kubitzki, K., Rohwer, J.G. \& Bittrich, V. (eds.). The families and genera of vascular plants, vol. 2, Flowering plants: Dicotyledons; Magnoliid, Hamamelid and Caryophyllid families. Berlin: Springer.

Gangadhara, M. \& Inamdar, J. A. 1977. Trichomes and stomata, and their taxonomic significance in the Urticales, Plant Syst. Evol., 127: 121-137.

Gaudichaud, C. 1830. Botanique, part 12. In: Freycinet, H.d. (Ed.), Voyage autour dumonde. executé sur les corvettes de S.M. 
l' Uranie et la Physiciene'. Pilet-Aine, Paris: 465-522, plates 111-120.

Ghafoor, A. 1981. Urticaceae, No.137. In: Flora of Pakistan. (Eds.): E. Nasir and S. I. Ali. Dept. Bot. Univ. Karachi and National Herberium. Pak. Agri. Research council, Islamabad.

Guerin, P. 1923. Les urticacees: cellules II mucilage, lactiferes etcanaux sccreteurs. Bull. Soc. Bot. Fr., 70: 125-136, 207-215, 255-263.

Hamdy, K. A.; Alaa, M. N. \& Mohamed, S. K. 2016. Botanical investigation of the leaf and stem of Forsskaolea tenacissima Linn., family Urticaceae, growing in Egypt. Inter. Journ. Pharma. Sci. Res., 1(3): 1219.

Hammer, Ø. 1999 - 2017. PAST Paleontological Statistics Version 3.16. Natural History Museum University of Oslo.

Hesse, M.; Halbritter, H.; Zetter, R.; Weber, M.; Buchner, R.; Frosch-Radivo, A. \& Ulrich, S. 2009. Pollen terminology. An illustrated Handbook. Springer, WienNew York.

Jafari, Z. \& Dehghan, M. 2012. Anatomical Structure Study of Aerial Organs in Four Populations of Urtica dioica L. Jour. Medic. Pl. By-products, 2: 133-137.

Johansen, D. A. 1940. Plant Microtechnique. McGraw-Hill Book Co., New York.

Kanwal, D.; Abid, R. \& Qaiser, M. 2012. The Seed Atlas of Pakistan- VI. Caryophyllaceae. Pak. J. Bot., 44 (1): 407424.

Kravtsova, T.I. 2009. In: Tzvelev, N.N., Vassilyev, A.E. (Eds.), Comparative
Carpology of the Urticaceae Juss. KMK Scientific Press, Moscow: 136-266.

Lersten, N. R. \& Curtis, J. D. 1991. Laminar hydathodes in Urticaceae: survey of tribes and anatomical observations on Pilea pumila and Urtica dioica. P1. Syst. Evol., 176:179-203.

Metcalfe, C. R. \& Chalk, L. 1950. Urticaceae. In: Anatomy of Dicotyledons, vol. 1. Clarendon Press, Oxford, 12441254.

Prabhakar, M. 2004. Structure, Delimitation, Nomenclature and Classification of Stomata. Acta Bot. Sinica, 46: 242-252.

Punt, W.; Hoen, P. P.; Blackmore, S.; Nilsson, S. \& Le Thomas, A. 2007. Glossary of pollen and spore terminology. Rev. Palaeobot. Palyn., 143: 1-81.

Sorsa, P., Huttunen, P. 1975. On the pollen morphology of the Urticaceae. Annales Botanici Fennici 12: 165-182.

Stace, C. A. 1984. The taxonomic importance of the leaf surface. In V. H. Heywood \& D. M. Moore (eds.) current concepts in plant taxonomy. Academic Press, London and Orlando U.K. 67-94.

Stearn, W. T. 1992. Botanical Latin $4^{\text {th }}$ ed. David and Charles Publication, London.

Stevens, P. F. 2001 onwards. Angiosperm Phylogeny Website. http:// www. mobot.org/MOBOT/research/APweb.

Täckholm, V. 1974. Student's Flora of Egypt $2^{\text {nd }}$ ed. Cairo University: 53-55.

Takhtajan, A. 2009. Flowering Plants $2^{\text {nd }}$ ed. Springer.

Weddell, H.A. 1869. Urticacées. In: Candolle, A.D. (Ed.), Prodromus Systematis Naturalis Regni Vegetabilis. Victoris Masson et Filii, Paris: 32-235. 